\title{
The Shift of Executive Power in The State Administrative System of the Republic of Indonesia: a Study on Presidential Powers on Legislation- Making
}

\author{
Fifiana Wisnaeni \\ \{fifiananenny@yahoo.co.id\} \\ Diponegoro University, Jl.Prof. H. Soedarto, S.H. Tembalang, Tembalang, Kota Semarang, Jawa \\ Tengah, 50275, Indonesia
}

\begin{abstract}
This research with the title of The Shifting of Executive Power in State Administrative System in Republic of Indonesia (A Study on Presidential Powers in Forming a Regulation) aims to know the background of the change of authority in forming a Law in Indonesia and the implications of the shift in power in creating a Law against the Regulation developing in Indonesia. The approach method that is used in this research is juridical normative, with the research specification of analytical descriptive. The data, which was secondary, are obtained through literature study. Data analysis is done qualitatively. From the result of the research, it can be concluded that the background of the authority change was because there was a change of authority that was stated in the Change of the 1945 Constitution of the Republic of Indonesia. The implication of the authority change towards the Regulation forming in Indonesia is that even though the Law is a law product that was created by an agreement between People's Representative Council and the President, the power domination to form regulation was in the People's Representative Council's (DPR) hand.

Keywords: State Administrative System, Separation of Powers, Executive Powers, Legislation-Making
\end{abstract}

\section{Introduction}

The amendments of the 1945 Constitution of the Republic of Indonesia were one of the reformation requirements that had brought a fundamental change to the constitutional law in Indonesia. This happened because such change had its impact towards one, the change of powers, tasks, and the authority of the People's Consultative Assembly; two, several new political institutions were formed, such as Constitutional Court, Judicial Commission, and the Regional's Consultative Assembly; and three, there were several political institutions that are changed or moved[1].

Not only that, based on the Change of the 1945 Constitution of the Republic of Indonesia, nowadays Indonesia does not embrace the division of powers system anymore, but now Indonesia embraces the separation of powers as in republic democracy system. In this system, the country's authority is divided by three branches of powers, which are the authority to form regulation (legislative), the authority to execute the regulation (executive), and the authority to supervise the execution of the regulation itself (judicative)[2].

Later at Article 1 clause (3) of the 1945 Constitution of the Republic of Indonesia, it was affirmed that Indonesia is a state of law, and according to this, Indonesia is a country that embraced the Continental European law tradition, or it was usually called as civil law 
system. One of the main characteristics of the civil law system is the importance of written law or "statutory laws" or "statutory legislation." The position of "statutory laws" took precedence over a verdict or jurisprudence [3].

Based on these, therefore in Indonesia, the position of legislation became critical. One type of legislation that has a critical position is Regulation. Based on the 1945 Constitution of the Republic of Indonesia, the authority to form regulation has shifted from the President's hand to the People's Representative Council's (DPR) hand. Based on the description above, so the problems that are to be analyzed in this research are: 1) What is the background of the change of authority in regulation forming in Indonesia?; 2) What is the implication of the change of authority in regulation forming towards the regulation forming itself in Indonesia?

\section{Method}

This article is based on doctrinal legal research. In doctrinal legal research, the analysis is based on secondary data that are texts and literature, whether those are legal or non-legal [4]. However, the specification of this research is analytical descriptive. Then, the secondary data that were obtained through literature research, will be analyzed qualitatively to obtain the purpose of the result of the research about the problems that will be discussed [5].

\section{Literature Review}

\subsection{Concept of Rule-of-Law Country}

Rule-of-law country is one of the existing laws which ensures justice for its citizens. Justice is the requirement for the achievement of life happiness for the citizens. According to Jimmy Asshiddiqie, there are twelve essential characteristics of a rule-of-law country. They are supremacy of law, equality before the law, due process of law, power restriction, executive organs of independent nature, free and impartial court, State Administrative Court, Constitutional Court, protection of human rights, of democratic nature (Democratische Rechtsstaat), Functioning as a Means of Realizing Welfare purpose (Welfare Rechtsstaat), and the existence of transparency and Social control [6].

\subsection{Process of Law Formation}

Under Article 1 point 2 of Law No. 12 the Year 2011 concerning on the Formation of Regulations of Law, the definition of regulations of law is written regulations which contain the publicly binding legal norms and formed or established by state institutions or relevant officials through a procedure set out in the Regulation of Law.

The process of law formation consists of 5 (five) steps:

\section{1) Planning}

The law to be formed should be planned in Prolegnas (Program Legislasi Nasional/National Legislation Program). This Prolegnas is formed by the House of Representatives together with the President. Prolegnas is the priority scale of Law formation program in the effort of bringing about the national legal system. 


\section{2) Preparation}

Based on its authority, the Preparation of Law Draft is performed by the House of Representatives (DPR), yet the President and the House of Representatives are also entitled to propose a Law Draft.

All Law Drafts, either coming from DPR, the President, or DPD should be equipped with Academic Script, which is a report of research or studies of law and other research on a particular issue which is scientifically accountable.

3) Discussion

The Discussion of Law Draft is done through 2 (two) levels of discussion; they are:

- level I discussion at a committee meeting, joint committee meeting, Legislation Body meeting, Budget Agency meeting, or Special Committee meeting; and

- level II discussion in a plenary meeting.

\section{4) Legalization or Stipulation}

Within the most extended period of 7 (seven) days commencing on the date of the joint agreement, a Law draft which is jointly agreed by The House of Representatives and President is delivered by the Head of the House of Representatives to the President in order to be enacted into a Law.

The President legalizes a legislative bill with his signature within the most extended period of 30 (thirty) days commencing on the date of a Law draft is agreed by the House of Representatives and the President.

In the event that the President does not sign the Law draft which is jointly agreed by the House of Representatives and the President within the most extended period of 30 (thirty) days commencing on the date of the jointly agreed Law draft, then the Law draft is valid to become and should be enacted into law. In this case, the legalization sentence says: this Law is considered valid based on the provisions of Article 20 paragraph (5) of the 1945 Constitution of the Republic of Indonesia. The legalization sentence should be added at the last page of the Law before enacting the Law draft into the State Gazette of the Republic of Indonesia.

\section{5) Enactment.}

To let the people know that a new Law is formed, the Law should be enacted in the State Gazette of the Republic of Indonesia. If the Law contains Explanations, those Explanations should be enacted in the Additional State Gazette of the Republic of Indonesia.

\section{Findings}

\subsection{Background of Authorization Changes in the Formation of Laws in Indonesia}

\subsubsection{Background and Basic Conception of Amendments of the 1945 Constitution of the Republic of Indonesia.}

The background of the change of the 1945 Constitution of the Republic of Indonesia is that there is a reformation demand [7]. The demand for change was based on the view that the old 1945 Constitution of the Republic of Indonesia was not enough to 
contain the base for democratic life, empowerment of the people, and respect of human rights[8]. Not only that, there were Articles that caused multi interpretation and open up opportunities of the execution of authoritarian state that is centralistic and closed with corruption, collusion, and nepotism practice which could lead to the social life's deterioration in various aspects of life[9]. In the developments, the demands of the 1945 Constitution of the Republic of Indonesia's change became Indonesian's need.

To follow up the public demands to make a change towards the 1945 Constitution of the Republic of Indonesia, so the People's Consultative Assembly as the institution which has the authority to change Constitution then made changes towards the 1945 Constitution of the Republic of Indonesia comprehensively, gradually, and systematically in four People's Consultative Assembly session since 1999 until 2002.

The change towards the 1945 Constitution of the Republic of Indonesia was done by the People's Consultative Assembly in accordance with its authority that was regulated in the Article 3 clause 37 of the 1945 Constitution of the Republic of Indonesia which stated that the People's Consultative Assembly had the authority to change and establish the Constitution with the requirements that the session is attended by at least $2 / 3$ of the members of the People's Consultative Assembly and the decision is taken with the agreement of at least $2 / 3$ of the members of the People's Consultative Assembly members that are present in the session.

The primary reasons that underlie the Amendments of the 1945 Constitution of The Republic of Indonesia are [10]:

- Forming the national government in which the highest authority is on the People's Consultative Assembly (MPR), which results in no checks and balances among the national government institution.

- Providing a high authority to the executive (president) that in facts the president is the chief executive functioning to implement the governance (equipped with various constitutional rights commonly called prerogative (including grass, amnesty, abolition, and rehabilitation) and legislative authority as having the authority to form Laws.

- Containing Articles which are too "flexible" that result in multi interpretations.

- I am providing too many authorities for the President to regulate various vital matters with Laws.

- The formulation on the State Coordinators' Spirit has not been adequately equipped with the constitutional regulations containing the fundamental rules regarding the communal life, Law Supremacy, People's Empowerment, respect on the Human Rights, and Regional Autonomy. Thus, it results in: a) no checks and balances among the National Government Institutions and the authority is central to the president, b) the political infrastructure formed, including political parties and community organizations, have less freedom of expressions that the functions are less optimal then they should be, c) General Election (Pemilihan umum/Pemilu) is held to meet the formal democratic requirements because the government authorizes all processes and implementation stages, and d) Social welfare based on Article 33 of the 1945 Constitution of the Republic of Indonesia is not achieved, yet in fact, the monopoly, oligopoly, and monopsony systems are well developed. 


\subsection{The Objectives of Amendments of the 1945 Constitution of the Republic of Indonesia.}

The amendments of the 1945 Constitution of the Republic of Indonesia aim at completing the necessary regulations:

- Concerning on National Governance to achieve the national goals as mentioned in the 1945 Constitution of the Republic of Indonesia

- Concerning on assurance, implementation of people's sovereignty, and expanding the people's participation to meet the development of democratic understanding

- Concerning on assurance and protection to Human Rights to meet the development of Human Rights and Civilizations.

- I am governing the Nation in democratic and modern ways, including through more assertive authority sharing equipped with checks and balances system.

- Constitutional Assurance and State Obligation in realizing social welfare, developing people's lives through education, upholding ethics, morality, and solidarity in social and national life based on the human respect and dignity in realizing the national welfare.

- I am governing the Nation for the State Existence and State Fight to realize the democracy.

- Concerning on State and National life based on the development of the present State and National aspiration, need, and interest to accommodate its tendency in the future.

\subsubsection{The implication of Authority Changes to Form Lawson The Formation of Laws in Indonesia}

The implication of the authority change to form regulation towards the Regulation forming itself in Indonesia is that the domination of the power to form a regulation shift from the President's hand to the People's Representative Council's hand [11]. However, this authority was not absolute, because like how it was regulated in Article 20 clause (2) of the 1945 Constitution of the Republic of Indonesia, every bill will be discussed by the People's Representative Council and the President to gain mutual agreement. In other words, even though Indonesia embraced the separation of powers system, the regulation is still a product that results from the People's Representative Council and the President, with a note that in bill submission, the People's Representative Council's powers are more dominant. Moreover, there are informal powers, in forms of non-governmental brokers, which mediate the public access to transparency and accountability of the government [12].

The People's Representative Council's domination was increasingly reaffirmed with the provision in the Article 51 of Regulation No. 12 Year 2011 about Forming of Legislation which states: "If in one trial period the People's Representative Council and the President submitted a Bill which has the same material, the Bill that will be discussed is the Bill that was submitted by the People's Representative Council and the Bill that was submitted by the President will be used as a material to be compared."

\section{Conclusion}

According to the research results, it can be concluded that the background of the authority change to form regulation in Indonesia is caused by the change of authority in the 
1945 Constitution of the Republic of Indonesia, where the authority to form regulation was in the People's Representative Council's hand, as the institution that held the legislative power and also the embracement of the separation of powers system which separates into three branches of powers, which are the authority to form regulation (legislative), the authority to execute the regulation (executive), and the authority to supervise the regulation execution itself (judicative) along with the checks and balances mechanism between the authority branches.

The implication of the change of authority to form regulation towards the regulation forming itself in Indonesia is that even though the Law is a legal product that needs mutual agreement between People's Representative Council and the President, the domination to form regulation lies on the People's Representative Council's hand.

\section{References}

[1] D. L. Horowitz, Constitutional change and democracy in Indonesia. 2010.

[2] B. Ghoshal, "Democratic Transition and Political Development in Post- Soeharto Indonesia," Contemp. Southeast Asia, 2004.

[3] T. Lindsey and M. A. Santosa, The Trajectory of Law Reform in Indonesia Indonesia: Law and Society (2nd edition). Annandale: The Federation Press, 2008.

[4] T. Hutchinson and N. Duncan, "Defining and Describing What We Do: Doctrinal Legal Research," Deakin Law Rev., 2012.

[5] M. van Hecke, Methodologies of Legal Research: Which kind of Method for What kind of Discipline? London: Hart Publishing, 2011.

[6] J. Asshiddiqie, "Universalization of Democratic Constitutionalism and The Work of Constitutional Courts Today," Const. Rev., 2016.

[7] J. S. Davidson, "Dilemmas of democratic consolidation in Indonesia," Pacific Rev., 2009.

[8] P. Eldrige, "Human Rights in Post-Suharto Indonesia," Brown J. World Aff., vol. 9, no. 1, p. 127, 2002.

[9] T. Lindsey, "Indonesian Constitutional Reform: Muddling Towards Democracy," in Public Law in East Asia, 2018.

[10] D. Webber, "A consolidated patrimonial democracy? Democratization in postSuharto Indonesia," Democratization, 2006.

[11] P. Stockmann, "Indonesia's struggle for rule of law," in Democratization in PostSuharto Indonesia, 2008.

[12] W. Berenschot, "Informal democratization: brokers, access to public services and democratic accountability in Indonesia and India," Democratization, 2019. 